\title{
Roadmap of Vocational Education Research at Engineering Faculty, Yogyakarta State University
}

\author{
Wagiran \\ Mechanical Engineering Education Department \\ Engineering Faculty, Yogyakarta State University \\ Yogyakarta, Indonesia \\ wagiran@uny.ac.id; maswagiran@yahoo.com
}

\begin{abstract}
This study was aimed at: (1) describing research mapping in Engineering Faculty, Yogyakarta State University (YSU); (2) roadmap formulation of Vocational Education Research at Engineering Faculty, YSU. This research and development was done at Engineering Faculty YSU. Samples were determined using purposive sampling technique. Data were collected through documentations, questionnaire and interview. The data were analyzed using descriptive methods. The result of study showed that: (1) majority of lecture research are educational, vocational educational, and technological subject. Majority research orientation are learning methods, research and development, and technical experiment; (2) roadmap was describe with three component: center for innovation of technology and vocational education, center for improving vocational education teachers, and improving education to produce excellence graduate.
\end{abstract}

Keywords-roadmap, research, vocational education.

\section{INTRODUCTION}

Research has a strategic role in efforts to realize the vision of higher education institutions. Data gathered from the Academic Unit of the Engineering Faculty, YSU, shows that each year there are more than 1500 research conducted by students and lecturers with various sources of financing. It would be meaningful if the studies is aligned with strategic issues, especially vocational education that has the optimal carrying capacity in accelerating the realization of the vision of the engineering Faculty. Therefore the question is, how much research in Engineering Faculty has optimal role in realizing the vision of the Engineering Faculty?. The next question is how the form of a roadmap as an effort to ensure the relevance of research and resources to support research in supporting the realization of the vision of the Engineering Faculty?. There has never been in-depth study of the relevance of the research to support the realization of the vision the Engineering Faculty. The absence of a roadmap resulting research done so far is not oriented to the realization of the vision of Engineering Faculty comprehensively.

In an effort to further strengthen the role of studies, it is necessary to study how the research roadmap formula to support realization of the vision of the Engineering Faculty. From the formulation of the roadmap is expected that all research conducted of the Engineering Faculty have optimal carrying capacity of the embodiment of the vision of Engineering Faculty.

The following definitions will help clarify the concept of research:

a. $\quad$ Research is a systematic attempt to provide answers to questions" (Tuckman, 1972: 1). The answer may be still abstract and general nature that is usually referred to as basic research as well as the answers that are concrete and specific so-called applied research.

b. The research method is a scientific method used to obtain data for specific purposes. Scientific way means that activities based on the scientific method is a combination of rational and empirical approach (Suriasumantri, 1978).

c. "Research can be defined as a search for a theory, theory testing, or solving a problem" (Sevilla, 1988). This means that the problem has existed and been known that solving the problem is needed.

d. Research defined as the application of a scientific approach to the study of a problem (Champion, 2001: 3). This is a way to obtain useful information and can be accounted for. The goal is to find answers to the question of meaning through the application of scientific procedures.

e. Scientific research is the study of systematic, controlled, empirical, and critical investigation of propositions and hypotheses about the relationship expected between natural phenomena (Kerlinger (1973). The study systematically when following the steps or stages that begin with identifying problems, linking the issue with existing theories, collect data, analyze data, conclusions, and incorporate these conclusions into the ranks repertoire of knowledge.

Based on some definitions, research can be formulated as a scientific approach that is systematic, controlled and empirical to obtain objective data, valid, reliable with the aim to find (describe), predict, test, and control the social phenomena with the hope to understand, anticipate and solve problems in the areas studied.

The purpose of scientific knowledge useful for (1) the description, (2) explanatory, and (3) predictive. The basis for all scientific inquiry is a description, list or categorize a series of elements which are seen as forming a field existing 
problems. Explanations can be used if the link between cause and effect that can be specified are shown. Forecasting is a business predict future events based on past information. Gay (1981: 5) argues: "The goal of all is to explain scientific endeavors, predict and/or control phenomenon". The purpose of all scientific inquiry is to describe, predict and control the phenomenon. Besides these objectives can also be grouped into find, prove and develop specific knowledge. The research hopes to be able to understand, solve and anticipate problems.

\section{METHODOLOGY}

This study was Research and Development carried out in stages as shown in Figure 1.

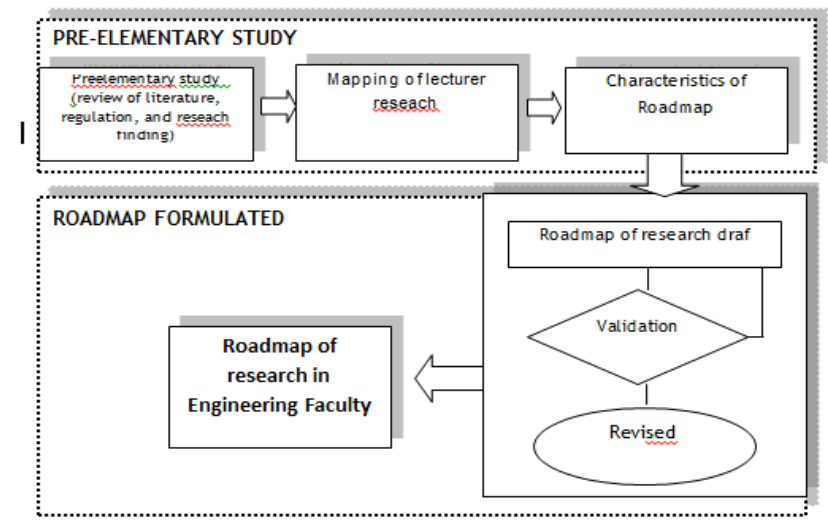

Figure 1. Stage of Study

Research activities begins with the study of literature, documents, results of research, observation, in-depth interviews with multiple sources to obtain a map of the results of research. Based on the results of the research maps are then conducted focus group to formulate a research roadmap. After revision, the draft roadmap validated content. The next stage is revised so that the resulting formulation research roadmap OF Engineering Faculty. This research was conducted at Engineering Faculty. To obtain the data necessary research conducted on experts, researchers and practitioners in various fields of research. Data were collected from studies of literature, and information from the field using documentation, observations, questionnaires, as well as in-depth interviews on a variety of informants. Data were analyzed descriptively.

\section{RESEARCH FINDINGS}

\section{A. Map Research of Engineering Faculty}

Map of study of Engineering Faculty conducted in 2013 can be seen at Table 1. In addition to the data presented in Table 1, also revealed that most of the research carried out within the scope of the Engineering Faculty. From 78 research number, there are 18 titles made within the scope of vocational High School, and 6 research conducted within the scope of non-formal education.
TABLE 1. MAP OF RESEARCH AT ENGINEERING FACULTY 2013

\begin{tabular}{|c|c|c|c|c|c|}
\hline \multirow[b]{2}{*}{ No } & \multirow[b]{2}{*}{ Component } & \multicolumn{3}{|c|}{ Finding Source } & \multirow[b]{2}{*}{ Sum } \\
\hline & & $\begin{array}{l}\text { DIPA } \\
\text { YSU }\end{array}$ & $\begin{array}{l}\text { BOPTN } \\
\text { YSU }\end{array}$ & $\begin{array}{l}\text { DPPM } \\
\text { (Higher } \\
\text { Ed. } \\
\text { Dept) }\end{array}$ & \\
\hline \multirow[t]{9}{*}{1} & Subject & & & & \\
\hline & Technologycal & 2 & 7 & 15 & 2 \\
\hline & Learning Methods & 2 & 4 & 8 & 2 \\
\hline & Learning Media & 1 & 1 & 4 & 1 \\
\hline & Assessment & 2 & 2 & 5 & 2 \\
\hline & Management & 1 & & 8 & 1 \\
\hline & Teachers & & 2 & 2 & \\
\hline & Curriculum & 1 & & & 1 \\
\hline & Etc & & & 9 & \\
\hline \multirow[t]{4}{*}{2} & Methods & & & & \\
\hline & $\begin{array}{l}\text { Technical } \\
\text { Experiment }\end{array}$ & 7 & 8 & 14 & 7 \\
\hline & $\mathrm{R} \& \mathrm{D}$ & 3 & 16 & 24 & 3 \\
\hline & Ex-post facto & 4 & & & 4 \\
\hline \multicolumn{2}{|c|}{ Sum } & 14 & 25 & 39 & 78 \\
\hline
\end{tabular}

\section{B. Formulation Research Roadmap}

Based on the study of literature, analysis of documents, and focuss group discussioan can be formulated that the preparation of research roadmap Engineering Faculty carried out with respect to some aspects:

a. Oriented demands of global developments, especially the demands of $21 \mathrm{st}$ century learning The Partnership for $21 \mathrm{st}$ Century Skills (www.21centuryskills.org) formulated the 21 st century student outcomes and support system shown in Figure 2.

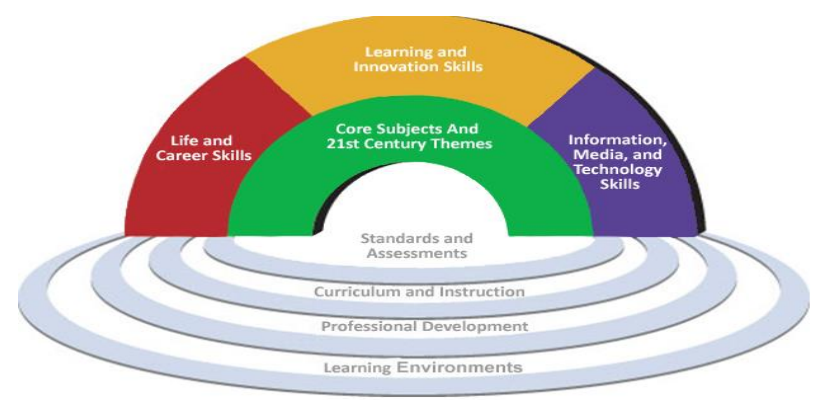

Figure 2. 21st Century Student Outcomes and Support System

Thought contained in Figure 1 shows how a holistic approach of learning needed to realize graduates who have a comprehensive competence. The competencies include aspects of basic skills (language, art, mathematics, economics, science, geographer, the history and citizenship); learning ability and innovation (creativity and innovation, critical thinking, communication, and collaboration); the ability to manage information, media, and information technology; as well as life skills and career (life and career skills). When viewed from the dimensions set out in the expected competencies, it seems clear that cultivation of character is a demand for graduates to be able to prevail in the coming era. 
b. Oriented to the National Policy: Indonesian Vision 2015 , Ministry of Education and Culture Strategic Plan, National Research Agenda, and Decentralization Research Paradigm. Engineering Faculty research roadmap drawn up within the framework of realization of the vision, mission, and goals of YSU by considering several related policies such as the Master Plan and Vision Innovation Indonesia 2025, the National Education Strategic Plan 2010-2014, the National Research, and the related policies

c. Oriented to YSU vision and Research Roadmap. YSU vision: in 2025 into a world-class university education based on faith, independence and scholarly. Research vision of YSU are: conduct research, development, and implementation of various fields of science education and non-educational (MIPA-Technology, Social Humanities, Sport and Health) mono and multidisciplinary towards world class university useful for improving the quality of human life and national in global and international scope. YSU research policy directed to improve the quantity and quality of research-multi and interdisciplinary in the field of educational and non-educational (MIPA-Technology, Social Humanities, Sport and Health) within the framework of the embodiment of the university education level of the world that contribute to solving the problems of local, national, regional and international.

d. Oriented Technology and Vocational Education Development in holistic approach which includes nine principles (Wagiran, 2008). The principles include:

1. Family conscious vocation education.

2. Vocational education from an early age.

3. Education in the sphere of vocational education pathways (formal, non-formal, informal), training, and work experience.

4. Vocational education friendly for the disabled (vocational education for disabled).

5. Gender responsive of vocational education.

6. Vocational education as a guide economic growth and nation competitiveness.

7. Vocational education dynamic, adaptive, predictive, and flexible to change, social dynamics and the development of science and technology.

8. quality-based vocational education.

An integrated and mutually beneficial collaboration between the students (graduate), business/industrial world, government, and society.

e. Oriented to the vision of Engineering Faculty. Engineering Faculty vision in the long term is: In 2025 became the faculty that excels in the field of technology and vocational education based on faith, independence, and scholarly. While in the short term are: Produce educational scholars and experts associate the field of technology and vocational professionals based on faith, independence, and scholarly in accordance with the demands of the development of science and technology in global era.
Based on the study, discussion and validation obtained research roadmap shown in Figure 1. Based on Figure 1 has been arranged roadmap study of Engineering Faculty with a target engineering Faculty as a reference to the quality of technology education and vocational development with three components: (1) Center of Innovation technology and vocational education development, (2) Center of vocational education teacher development, (3) Produces Excellent graduate, professional character, competitive, global insight.

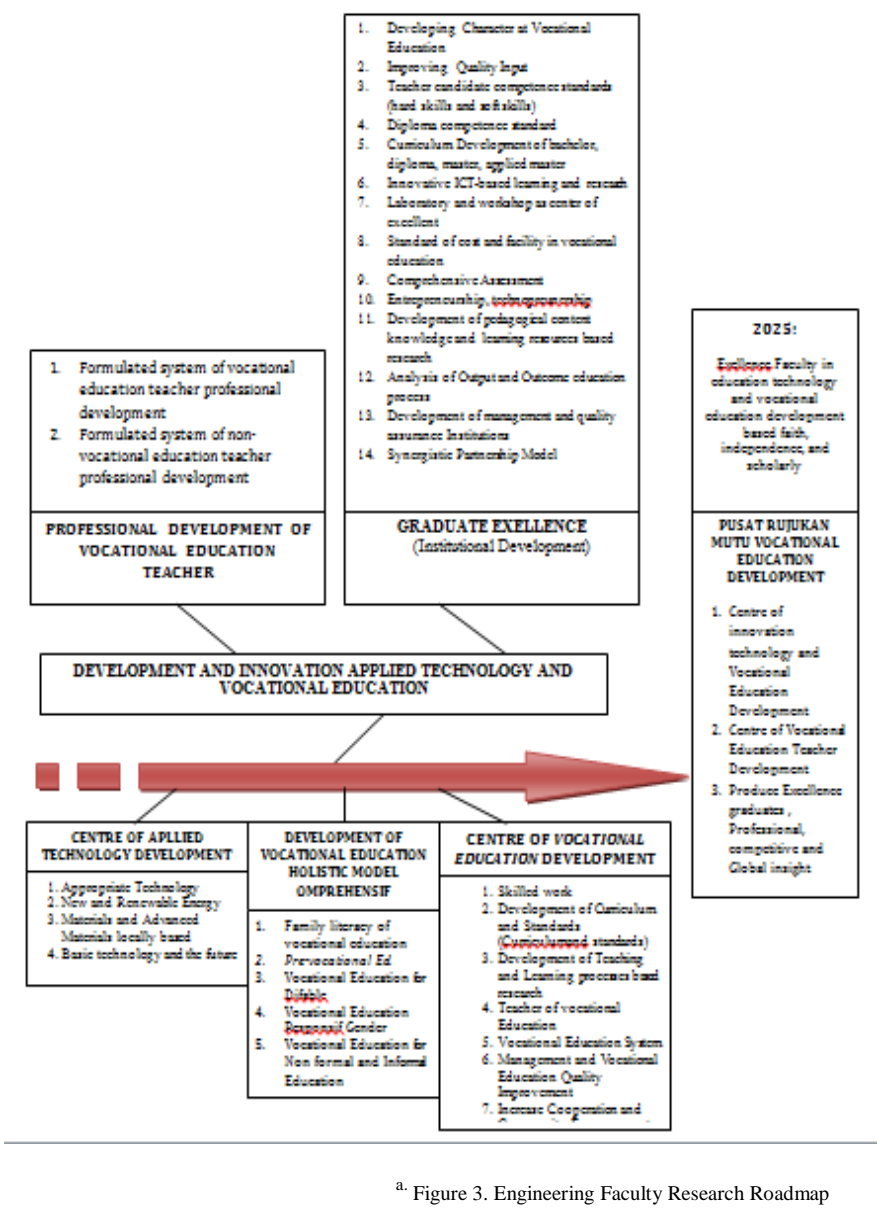

IV. CONCLUSION

An effort to improve the quality of research alignment with the vision, mission and goals of the of Engineering Faculty, the research should be based on the roadmap that reflects the development of holistic vocational education. Therefore, the roadmap that resulted from this research study is one of the main ingredients that can be used to formulate better research.

\section{REFERENCES}

[1] Champion Dean, J., Basic Statistic for Social Research. New York: Mc Millan Publishing. Co, 1981

[2] Gay, Educational Research. London: Charles E. Merril Publishing Co.

[3] Kerlinger, Fred, N, Foundation of Behavioral Research. New York: Holt Rinehard, 1973

[4] Tuckman, B., Conducting Educational Research. New York: HBJ, Inc, 1972. 
[5] 21st Century Student Outcome and Support System. www.21stcenturyskills.org., 23 April 2011

[6] Suriasumantri, J., Filsafat Ilmu. Jakarta: Pustaka Sinar Harapan. 1978

[7] Sevilla, C.G., An Introduction to Research Methods. Phillipines: Rex Printing Company, Inc. 1988.
[8] Wagiran. Butir-butir Pemikiran Pengembangan Pendidikan Vokasi Secara Holistik.International Seminar of Vocational Education. UNP Padang. 2008. 